\title{
СТАН ПРООКСИДАНТНО-АНТИОКСИДАНТНОЇ СИСТЕМИ ПЕЧІНКИ АЛОКСАНДІАБЕТИЧНИХ ЩУРІВ ЗА УМОВ ВВЕДЕННЯ МЕЛАТОНІНУ
}

Вступ. Експериментальну модель алоксанового чукрового діабету досить часто використовують для вивчення патогенезу діабету. При цукровому діабеті посилюється оксидативний стрес, що призводить до виснаження антиоксидантної системи. Мелатонін $є$ антиоксидантом, що активізує захисні сили організму, оберігаючи його від захворювань, пов'язаних з активацією вільнорадикальних процесів.

Мета дослідження - визначити вплив мелатоніну на про- та антиоксидантний статус у печінці алоксандіабетичних щурів.

Методи дослідження. Досліди проведено на білих безпородних статевозрілих щурах-самцях. Експериментальний алоксановий цукровий діабет у них було викликано одноразовим внутрішьочеревним введенням 5 \% розчину моногідрату алоксану в дозі 150 мг/кг після 24-годинного голодування. Мелатонін вводили інтрагастрально впродовж 7-ми та 14-ти днів у дозі 10 мг/кг маси тіла щура. У печінці визначали вміст окисномодифрікованих білків, ТБК-активних продуктів, активність каталази ісупероксиддисмутази.

Результати й обговорення. Результати наших досліджень показали, що за умов алоксанового цукрового діабету активувалося вільнорадикальне окиснення біомолекул, про що свідчило збільшення вмісту ТБК-активних продуктів та окисномодифрікованих білків у печінці алоксандіабетичних щурів на 7-й і 14-й дні експерименту. Одночасно спостерігали зниження активності каталази і супероксиддисмутази в печінці тварин діабетичної групи. Введення мелатоніну мало позитивний ефект, що проявився зменшенням вмісту ТБК-активних продуктів і окисномодифрікованих білків у печінці щурів порівняно з показниками алоксандіабетичних тварин. Крім того, застосування мелатоніну сприяло нормалізації активності антиоксидантних ензимів печінки в щурів з алоксановим діабетом: підвищенню активності каталази і супероксиддисмутази порівняно з показниками тварин діабетичної групи.

Висновок. При алоксановому цукровому діабеті та введенні щурам екзогенного мелатоніну в дозі 10 мг/кг щоденно впродовж 7-ми та 14-ти днів спостерігають зменшення вільнорадикального окиснення та нормалізацію активності ензимів антиоксидантного захисту в печінці алоксандіабетичних щурів.

КЛЮЧОВІ СЛОВА: алоксановий цукровий діабет; мелатонін; печінка; прооксидантно-антиоксидантна система.

ВСТУП. Цукровий діабет (ЦД) - це порушення обміну речовин внаслідок десріциту секреції інсуліну та/або дії інсуліну, що призводить до гіперглікемії [1]. Він характеризується високою захворюваністю в усьому світі.

При гіперглікемії відбувається збільшення реакцій, пов'язаних з оксидативним стресом. Вільні радикали, що утворюються при оксидативному стресі, є високотоксичними для клітинних компонентів, особливо ліпідів і білків, які входять до складу клітинних мембран. Ці радикали індукують окисну модифрікацію ліпідів і білків клітинних мембран, що в подальшому супроводжується ушкодженням клітин [2].

Печінка є головною мішенню для дії несприятливих фракторів і забезпечує знешкодження токсичних продуктів, які надходять в організм та () Н. М. Лугініч, І. В. Геруш, Н. П. Григор'єва, 2019. утворюються в процесі метаболізму. Високі рівні вільних радикалів при ЦД порушують здатність печінки до регенерації. Продукти окиснення ліпідів і білків метаболізуються неензиматичними й ензиматичними механізмами для усунення оксидативного стресу [3].

Попередні дослідження продемонстрували, що мелатонін може захищати від деяких ускладнень ЦД, пов'язаних з ушкодженням підшлункової залози, печінки, нирок та нейронів. Він може також зменшувати гіперглікемію і поліпшувати десенсибілізацію інсуліну [4].

Враховуючи зростання потреби в знаннях про вплив ЦД на печінку, метою дослідження було визначити вплив мелатоніну на про- та антиоксидантний статус у печінці алоксандіабетичних щурів. 
МЕТОДИ ДОСЛІДЖЕННЯ. Досліди проведено на білих безпородних статевозрілих щурахсамцях масою 0,15-0,18 кг. Експериментальний алоксановий цукровий діабет у них було викликано одноразовим внутрішьочеревним введенням $5 \%$ розчину моногідрату алоксану в дозі 150 мг/кг [5] після 24-годинного голодування. Концентрацію глюкози в крові визначали натще за допомогою приладу "Longevita" (виробник "Network Selects LTD", Велика Британія). Кров для дослідження відбирали з хвостової вени. Тварин 3 концентрацією глюкози в крові $\geq 15,2$ ммоль/л вважали діабетичними і використовували в цьому дослідженні. Щурів поділили на групи: 1-ша - контрольні тварини; 2-га тварини із ЦД (7 днів); 3-тя - тварини із ЦД, яким щоденно впродовж 7-ми днів о 8 год ранку інтрагастрально вводили мелатонін у дозі $10 \mathrm{mг/кг}$ маси; 4-та - тварини із ЦД (14 днів); 5-та - тварини із ЦД, яким щоденно впродовж 14-ти днів о 8 год ранку інтрагастрально вводили мелатонін у дозі 10 мг/кг маси.

Тварин виводили з експерименту шляхом декапітації під легким ефрірним наркозом 3 дотриманням вимог загальних етичних принципів експериментів на тваринах, ухвалених на Першому національному конгресі України з біоетики (Київ, 2001), Європейської конвенції про захист хребетних тварин, що використовуються для дослідних та інших наукових цілей (Страсбург, 1986). Печінку швидко вирізали, промивали в охолодженому льодом фрізіологічному розчині, промокали, заморожували в рідкому азоті й зберігали при температурі - $20^{\circ} \mathrm{C}$ до використання. Визначали в ній вміст ТБК-активних продуктів [6], окисномодиорікованих білків [7], активність каталази [8] і супероксиддисмутази [9]. Варіаційно-статистичне опрацювання даних здійснювали 3 використанням програмного пакета для персональних комп'ютерів Microsoft Excel із застосуванням непараметричних методів варіаційної статистики (розрахунок середніх значень (М), похибки середніх значень (m), U-критерію Уілкоксона). Вірогідною вважали різницю при $\mathrm{p}<0,05$.

РЕЗУЛЬТАТИ Й ОБГОВОРЕННЯ. АКТИВНі форми оксигену індукують пероксидне окиснення ліпідів, що викликає ушкодження мембрани, на додаток до змін проникності іонів порушується активність ензимів і, в кінцевому результаті, настає клітинна смерть. Малоновий діальдегід $€$ індикатором окисного ушкодження, що утворюється при пероксидному окисненні ліпідів $[2,3]$.

Встановлено, що за умов алоксанового ЦД посилювалися процеси вільнорадикальних ушкоджень біомолекул, про що свідчило значне зростання вмісту ТБК-активних продуктів у печінці на 7-й день алоксаніндукованого діабету на 33 \% (табл.). На 14-й день ЦД вміст цих продуктів збільшився на 42 \% порівняно з показниками контрольної групи.

Окисна модифрікація та руйнування білків $€$ одним з найбільш ранніх і важливих показників ушкодження тканин при вільнорадикальних патологіях. Масове продукування вільних радикалів дає початок утворенню білок-білкових і білок-ліпідних поперечних зв'язків, які, у свою чергу, змінюють структуру та фрункцію білків, викликають їх фррагментацію і модифрікації бічних ланцюгів амінокислот. Ці зміни зумовлюють інгібування ензиматичних властивостей, підвищення здатності до агрегації, стійкості до протеолізу чи зміни імуногенної активності [10].

Досліджено, що на 7-й день експерименту вміст окисномодифікованих білків у печінці алоксандіабетичних щурів збільшувався на $19 \%$ вище контрольного рівня, а на 14-й день алоксанового ЦД - на $14 \%$.

Важливими показниками розвитку оксидативного стресу $є$ активність ензимів антиоксидантного захисту. Відомо, що при індукції алоксаном у тварин утворюються активні форми

Таблиця - Стан прооксидантно-антиоксидантної системи печінки алоксандіабетичних щурів за умов введення мелатоніну $(\mathrm{M} \pm \mathrm{m})$

\begin{tabular}{|c|c|c|c|c|c|}
\hline \multirow{2}{*}{ Показник } & \multirow{2}{*}{ Контроль } & \multicolumn{2}{|c|}{ 7-й день } & \multicolumn{2}{|c|}{ 14-й день } \\
\hline & & ЦД & мелатонін & ЦД & мелатонін \\
\hline $\begin{array}{l}\text { Каталаза, } \\
\text { мкМ/хв·г білка }\end{array}$ & $44,46 \pm 2,49$ & $33,96 \pm 3,78^{*}$ & $41,25 \pm 1,42^{\#}$ & $35,18 \pm 2,53^{\star}$ & $45,74 \pm 2,17^{\# \#}$ \\
\hline $\begin{array}{l}\text { Супероксиддисмутаза, } \\
\text { Од/мг білка }\end{array}$ & $0,79 \pm 0,04$ & $0,65 \pm 0,05^{\star}$ & $0,73 \pm 0,05$ & $0,57 \pm 0,06^{\star *}$ & $0,68 \pm 0,03$ \\
\hline $\begin{array}{l}\text { ТБК-активні продукти, } \\
\text { мкМ/г тканини }\end{array}$ & $24,48 \pm 1,39$ & $32,60 \pm 3,83^{*}$ & $25,71 \pm 4,07^{\#}$ & $34,83 \pm 4,96^{\star}$ & $24,20 \pm 2,27^{\#}$ \\
\hline $\begin{array}{l}\text { Окисномодифріковані } \\
\text { білки, мкМ/г білка }\end{array}$ & $1,88 \pm 0,08$ & $2,23 \pm 0,10^{*}$ & $1,87 \pm 0,08^{\# \#}$ & $2,14 \pm 0,04^{*}$ & $1,81 \pm 0,06^{\# \#}$ \\
\hline
\end{tabular}

Примітки:

1. Різниця вірогідна порівняно з контрольною групою $\left({ }^{*}-p<0,05\right.$, ** $\left.-p<0,01\right)$.

2. Різниця вірогідна порівняно з алоксандіабетичною групою (\# - p<0,05, $\left.{ }^{\#}-p<0,01\right)$. 
оксигену, особливо супероксид-аніон радикал і пероксид гідрогену [11], та відбувається інактивація ензимів, які їх розщеплюють, зокрема супероксиддисмутази і каталази. Це підтверджується зниженням активності даних ензимів у печінці алоксандіабетичних щурів порівняно 3 тваринами контрольної групи.

В алоксандіабетичних щурів ми зафріксували зменшення активності супероксиддисмутази в печінці порівняно з показниками тварин контрольної групи: на $18 \%$ - на 7-й день, на $28 \%$ на 14-й. На 7-й день активність каталази в печінці алоксандіабетичних щурів зменшилася на 24 \% нижче контрольного рівня. На 14-й день експерименту спостерігали зменшення цього показника на 21 \%, аналогічно 7-му дню. Отже, зниження активності каталази і супероксиддисмутази може бути зумовлене ослабленням антиоксидантної системи захисту.

Мелатонін - високоесрективний ендогенний антиоксидант при різних патологічних станах. Важливим аспектом дії мелатоніну є його вплив на прооксидантно-антиоксидантну систему і знешкодження вільних радикалів, що генеруються при ЦД [4]. Мелатонін істотно знижує оксидативний стрес за рахунок регуляції циркулюючих адипокінів, які беруть участь в енергетичному гомеостазі організму [12].

Було встановлено, що введення мелатоніну щурам з алоксановим діабетом щодня протягом 7-ми днів сприяло зниженню вмісту в печінці ТБК-активних продуктів (на 21 \%) і окисномодифрікованих білків (на 16 \%) порівняно з показниками алоксандіабетичних тварин. Позитивний есрект мелатоніну спостерігали і на 14-й день експерименту. Він проявлявся зменшенням вмісту в печінці щурів ТБК-активних продуктів (на 31 \%) і окисномодисрікованих білків (на $15 \%$ ) порівняно $з$ показниками алоксандіабетичних тварин.

Введення мелатоніну також сприяло нормалізації активності антиоксидантних ензимів печінки щурів з алоксановим діабетом: після 7-ми днів його введення активність каталази і супероксиддисмутази була вищою на 12 та $19 \%$, після 14-ти днів - на 21 і 30 \% відповідно порівняно з показниками алоксандіабетичних тварин.
Також у попередніх дослідженнях ми виявили зниження рівня глюкози в крові щурів 3 алоксаніндукованим цукровим діабетом, яким вводили мелатонін [13].

Отримані результати свідчать про ефективність застосування мелатоніну для корекції антиоксидантної системи захисту при експериментальному ЦД. Він володіє амсріфрільними властивостями, тобто розчиняється як у воді, так і в жирах, завдяки чому долає всі тканинні бар'єри, впливаючи на внутрішньоклітинні процеси як минаючи систему рецепторів та сигнальних молекул, так і шляхом взаємодії з ядерними та мембранними рецепторами $[4,14]$. Порівняно 3 іншими антиоксидантами мелатонін має багато переваг. Він може безпосередньо знешкоджувати гідроксильний радикал. Деякі метаболіти, які генеруються при інактивації токсичних реагентів мелатоніном, здатні безпосередньо знешкоджувати вільні радикали. Крім прямої дії як поглинача вільних радикалів, він також стимулює ряд антиоксидантних ензимів та зменшує витік електронів на мітохондріальному рівні, що дозволяє уникнути генерації вільних радикалів [12]. Поєднання цих есректів мелатоніну, поряд 3 низькою токсичністю і здатністю проникати через морфрофрізіологічні мембрани, робить його найбільш сильним і універсальним ендогенним антиоксидантом.

ВИСНОВКИ. За умов алоксанового ЦД посилюються процеси вільнорадикальних ушкоджень біомолекул, про що свідчить збільшення вмісту ТБК-активних продуктів і окисномодифрікованих білків у печінці алоксандіабетичних щурів. Зниження активності каталази і супероксиддисмутази може бути зумовлене ослабленням антиоксидантної системи захисту при ЦД. Введення мелатоніну сприяє нормалізації вмісту ТБК-активних продуктів і окисномодифікованих білків та активності антиоксидантних ензимів - каталази і супероксиддисмутази. Отже, крім прямої антиоксидантної дії, мелатонін може впливати на активність антиоксидантних ензимів. Це свідчить про потужні захисні фрункції мелатоніну при ЦД.

\section{СПИСОК ЛІТЕРАТУРИ}

1. Pancreatic beta cell death: novel potential mechanisms in diabetes therapy [Electronic resource] / J. Rojas, V. Bermudez, J. Palmar [et al.] // Journal of Diabetes Research. -2018. -Article ID 9601801. -P. 19. doi.org/10.1155/2018/9601801.
2. Hyperglycemia aggravates hepatic ischemia reperfusion injury by inducing chronic oxidative stress and inflammation [Electronic resource] / Y. Zhang, D. Yuan, W. Yao [et al.] // Oxidative Medicine and Cellular Longevity. - 2016. - 3919627. doi:10.1155/2016/3919627. 
3. Effect of dexmedetomidine on ischemia-reperfusion injury of liver and kidney tissues in experimental diabetes and hepatic ischemia-reperfusion injury induced rats / S. C. Sezen, B. Işık, M. Bilge [et al.] // Anaesth. Pain \& Intensive Care. - 2016. - No. 20 (2). - P. 143-149.

4. Melatonin ameliorates hypoglycemic stress-induced brain endothelial tight junction injury by inhibiting protein nitration of TP53-induced glycolysis and apoptosis regulator [Electronic resource] / C. K. Wang, M. M. Ahmed, Q. Jiang. [et al.] // J. Pineal Res. - 2017. No. 63 (4). - e12440. doi:10.1111/jpi.12440.

5. Akinola O. Treatment of alloxan-induced diabetic rats with metformin or glitazones is associated with amelioration of hyperglycaemia and neuroprotection / O. Akinola, M. Gabriel, A. Suleiman // The Open Diabetes Journal. - No. 5. - P. 8-12.

6. Камышников В. С. Справочник по клиникобиохимической лабораторной диагностике / В. С. Камышников. - Минск : Беларусь, 2002. - 494 с.

7. Мещишен І. Ф. Метод визначення окисномодифрікованих білків плазми (сироватки) крові / І. Ф. Мещишен // Буковин. мед. вісн. - 1998. - 2, № 1. C. 156-158.

8. Метод определения активности каталазы / К. А. Королюк, Л. И. Иванова, И. Г. Майорова, В. Е. Токарев // Лаб. дело. - 1988. - № 1. - С. 16-19.

9. Дубинина Е. Е. Активность и изоэнзимный спектр супероксиддисмутазы эритроцитов и плазмы крови человека / Е. Е. Дубинина, Л. Я. Сальникова, Л. Ф. Ефиимова // Лаб. дело. - 1983. - № 10. - С. 30-33.

10. Mechanisms of diabetes-induced liver damage: The role of oxidative stress and inflammation [Electronic resource]/ J. Mohamed, A. H. Nazratun Nafizah, A. H. Zariyantey, S. B. Budin // Sultan Qaboos University Medical Journal. -2016. - 16, No. 2. -P. e132-e141. doi:10.18295/ squmj.2016. 16.02.002.

11. Espino J. Role of melatonin on diabetes-related metabolic disorders / J. Espino, J. A. Pariente, A. B Rodríguez // World J. Diabetes. - 2011. - No. 2 (6). P. 82-91.

12. Melatonin supplementation lowers oxidative stress and regulates adipokines in obese patients on a calorie-restricted diet [Електронний ресурс] / K. Szewczyk-Golec, P. Rajewski, M. Gackowski [et al.] // Oxidative Medicine and Cellular Longevity. - 2017. - P. 8494107. doi:10.1155/2017/8494107.

13. Вплив 14 добового введення мелатоніну на метаболізм глутатіону в печінці щурів при алоксановому цукровому діабеті / Н. М. Лугініч, І. В. Геруш, І. М. Яремій, Н. В. Давидова // Наук. записки Терноп. нац. пед. ун-ту імені Володимира Гнатюка. Серія "Біологія". - 2018. - № 3-4 (74). - С. 71-75.

14. Bonnefond $A$. The case for too little melatonin signalling in increased diabetes risk / A. Bonnefond, P. Froguel // Diabetologia. -2017. - No. 60 - P. 823-825.

\section{REFERENCES}

1. Rojas, J., Bermudez, V., Palmar, J. Martínez, M.S., Olivar, L.C., Nava, M., Tomey, D., Rojas M., Salazar, J., Garicano, C., \& Velasco, M. (2018). Pancreatic beta cell death: novel potential mechanisms in diabetes therapy. Journal of Diabetes Research. Article ID 9601801, 19. doi.org/10.1155/2018/9601801.

2. Zhang, Y., Yuan, D., Yao, W., Zhu, Q., Liu, Y., Huang, F., ... Hei, Z. (2016). Hyperglycemia aggravates hepatic ischemia reperfusion injury by inducing chronic oxidative stress and inflammation. Oxidative Medicine and Cellular Longevity. 3919627. doi:10.1155/2016/ 3919627

3. Sezen, S.C., Işık, B., Bilge, M., Arslan, M., Çomu, F.M., Öztürk, L., Kesimci, E., Kavutçu, M. (2016). Effect of dexmedetomidine on ischemia-reperfusion injury of liver and kidney tissues in experimental diabetes and hepatic ischemia-reperfusion injury induced rats. Anaesth Pain \& Intensive Care, 20 (2), 143-149.

4. Wang, C.K., Ahmed, M.M., Jiang, Q., Lu, N., Tan, C., Gao, Y., ... Han, F. (2017). Melatonin ameliorates hypoglycemic stress-induced brain endothelial tight junction injury by inhibiting protein nitration of TP53-induced glycolysis and apoptosis regulator. J. Pineal Res., 63 (4), e12440. doi:10.1111/jpi.12440.

5. Akinola, O., Gabriel, M., \& Suleiman, A. (2012). Treatment of alloxan-induced diabetic rats with metformin or glitazones is associated with amelioration of hyperglycaemia and neuroprotection. The Open Diabetes Journal, 5, 8-12.
6. Kamyshnikov, V.S. (2002). Spravochnik po klinikobiokhimicheskoy laboratornoy diagnostike (2nd ed.) [Handbook of clinical and biochemical laboratory diagnostics]. Minsk [in Russian].

7. Meshchyshen, I.F. (1998). Metod vyznachennia okysno modyfikovanykh bilkiv plazmy (syrovatky) krovi [Method of determination of oxidative modifiers of plasma (serum) of blood]. Bukovynskyi medychnyi visnyk Bukovyna Medical Bulletin, 2, (1), 156-158 [in Ukrainian].

8. Koroliuk, K.A., Ivanova, L.I., \& Maiorova, I.G. (1988). Metod opredeleniya aktivnosti katalazy [Method of determination of catalase activity]. Laboratornoye delo - Laboratory Work, 1, 16-19 [in Russian].

9. Dubynina, E.E., Salnykova, L.A., \& Efymova, L.F. (1983). Aktivnost i izofermentnyy spektr superoksyddismutazy eritrotsytov y plazme krovi cheloveka [Activity and isoenzyme spectrum of erythrocyte superoxide dismutase and human blood plasma]. Laboratornoye delo - Laboratory Work, 10, 30-33 [in Russian].

10. Mohamed, J., Nazratun Nafizah, A. H., Zariyantey, A.H., \& Budin, S.B. (2016). Mechanisms of diabetesinduced liver damage: The role of oxidative stress and inflammation. Sultan Qaboos University Medical Journal, 16 (2), e132-e141. doi:10.18295/squmj.2016.16. 02.002 .

11. Espino, J., Pariente, J.A., \& Rodríguez, A.B. (2011). Role of melatonin on diabetes-related metabolic disorders. World J. Diabetes, 2 (6), 82-91. 
12. Szewczyk-Golec, K., Rajewski, P., Gackowski, M., Mila-Kierzenkowska, C., Wesołowski, R., Sutkowy, P., ... Woźniak, A. (2017). Melatonin supplementation lowers oxidative stress and regulates adipokines in obese patients on a calorie-restricted diet. Oxidative Medicine and Cellular Longevity, 2017, 8494107. doi:10.1155/2017/ 8494107.

13. Luhinich, N.M., Herush, I.V., Yaremii, I.M., \& Davydova, N.V. (2018). Vplyv 14 dobovoho vvedennia melatoninu na metabolizm hlutationu v pechintsi shchuriv pry aloksanovomu tsukrovomu diabeti [Influence of 14 daily administration of melatonin on glutathione metabolism in rat liver with aloxane diabetes mellitus]. Naukovi zapysky Ternopilskoho natsionalnoho pedahohichnoho universytetu imeni Volodymyra Hnatiuka. Seriia: Biolohiia - Scientifical Notes of Ternopil National Pedagogical University named after Volodymyr Hnatiuk. Series "Biology", 3-4 (74), 1-75 [in Ukrainian].

14. Bonnefond, A., \& Froguel, P. (2017). The case for too little melatonin signalling in increased diabetes risk. Diabetologia, 60, 823-825.

\section{СОСТОЯНИЕ ПРООКСИДАНТНО-АНТИОКСИДАНТНОЙ СИСТЕМЫ ПЕЧЕНИ АЛЛОКСАНДИАБЕТИЧЕСКИХ КРЫС ПРИ ВВЕДЕНИИ МЕЛАТОНИНА}

\section{Резюме}

Вступление. Экспериментальную модель аллоксанового сахарного диабета достаточно часто используют для изучения патогенеза диабета. При сахарном диабете усиливается оксидативный стресс, что приводит к истощению антиоксидантной системы. Мелатонин является антиоксидантом, который активизирует защитные силы организма, защищая его от заболеваний, связанных с активацией свободнорадикальных процессов.

Цель исследования - определить влияние мелатонина на про- и антиоксидантный статус в печени аллоксандиабетических крыс.

Методы исследования. Опыты проведены на белых беспородных половозрелых крысах-самцах. Экспериментальный аллоксановый сахарный диабет у них был вызван однократным внутрибрюшным введением 5 \% раствора моногидрата аллоксана в дозе 150 мг/кг после 24-часового голодания. Мелатонин вводили интрагастрально в течение 7-ми и 14-ти дней в дозе 10 мг/кг массы тела крысы. В печени определяли содержание окислительномодифрицированных белков, ТБК-активных продуктов, активность каталазы и супероксиддисмутазы.

Результаты и обсуждение. Результаты наших исследований показали, что в условиях аллоксанового сахарного диабета активизировалось свободнорадикальное окисление биомолекул, о чем свидетельствовало увеличение содержания ТБК-активных продуктов и окислительномодифицированных белков в печени аллоксандиабетических крыс на 7-й и 14-й дни эксперимента. Одновременно наблюдали снижение активности каталазы и супероксиддисмутазы в печени животных диабетической группы. Введение мелатонина имело положительный эфрфект, который проявился уменьшением содержания ТБК-активных продуктов и окислительномодифицированных белков в печени крыс по сравнению с показателями аллоксандиабетических животных. Кроме того, применение мелатонина способствовало нормализации активности антиоксидантных энзимов печени у крыс с аллоксановым диабетом: повышению активности каталазы и супероксиддисмутазы по сравнению с показателями животных диабетической группы.

Вывод. При аллоксановом сахарном диабете и введении крысам экзогенного мелатонина в дозе 10 мг/кг ежедневно в течение 7-ми и 14-ти дней наблюдают уменьшение свободнорадикального окисления и нормализацию активности энзимов антиоксидантной защиты в печени аллоксандиабетических крыс.

КЛЮЧЕВЫЕ СЛОВА: аллоксановый сахарный диабет; мелатонин; печень; прооксидантно-антиоксидантная система. 


\section{THE STATE OF THE PROOXIDANT-ANTIOXIDANT SYSTEM IN THE LIVER OF ALLOXAN DIABETIC RATS IN THE CONDITIONS OF MELATONIN INTRODUCTION}

\section{Summary}

Introduction. An experimental model of alloxan diabetes mellitus is often used to study the pathogenesis of diabetes. In diabetes, oxidative stress is increased, which leads to depletion of the antioxidant system. Melatonin is an antioxidant and activates the body's defenses, protecting it from diseases associated with the activation of free radical processes.

The aim of the study - to determine the effect of melatonin on the prooxidant and antioxidant status in the liver of alloxan diabetic rats.

Research Methods. Experiments were conducted on white outbred sexually mature male rats. The content of oxidatively modified proteins, TBA-active products, the activity of catalase and superoxide dismutase (SOD) was determined in the liver.

Results and Discussion. The results of our research showed that under the conditions of alloxan diabetes mellitus is activation of free radical oxidation of biomolecules, as evidenced increase the content of TBA-products and oxidatively modified proteins on the 7th and 14th days of the experiment in the liver of alloxane diabetic rats. At the same time, decrease of activity of catalase and superoxide dismutase is observed in the liver of rats in diabetic group. The positive effect of melatonin is shown in the decrease the content of TBA-active products and oxidatively modified proteins in the liver compared to group of alloxan diabetic animals. In addition, the use of melatonin contributed to the normalization the activity of antioxidant enzymes in rat liver with alloxan diabetes: increase the activity of catalase and superoxide dismutase compared to diabetic group.

Conclusion. In the conditions of exogenous melatonin introduction to rats with alloxan diabetes in a dose of $10 \mathrm{mg} / \mathrm{kg}$ daily for 7 and 14 days cause a pronounced antioxidant effect, reducing free radical oxidation and normalizing the activity of enzymes of antioxidant defense in the liver of alloxan diabetic rats.

KEY WORDS: alloxan diabetes mellitus; melatonin; liver; prooxidant-antioxidant system.

Отримано 23.04.19

Адреса для листування: Н. М. Лугініч, Буковинський державний медичний університет, Театральна площа, 2, Чернівці, 58001, україна, e-mail: nlevytska@ukr.net. 